\title{
Migration of the bivalve Macoma balthica on a highly dynamic tidal flat in the Westerschelde estuary, The Netherlands
}

\author{
H. Bouma ${ }^{1, *}$, P. P. de Vries ${ }^{2}$, J. M .C. Duiker ${ }^{3}$, P. M. J. Herman ${ }^{2}$, W. J. Wolff ${ }^{1}$ \\ ${ }^{1}$ Department of Marine Biology, Groningen University (RUG), PO Box 14, 9750 AA Haren, The Netherlands \\ ${ }^{2}$ Department of Ecosystem Studies, Netherlands Institute of Ecology (NIOO), PO Box 140, 4400 AC Yerseke, The Netherlands \\ ${ }^{3}$ Department of Physical Geography, Utrecht University (UU), PO Box 80115, 3508 TC Utrecht, The Netherlands
}

\begin{abstract}
Population dynamics of the tellinid clam Macoma balthica (L.) were studied at a highly dynamic intertidal sandflat in the Westerschelde estuary, south-western Netherlands. In order to study temporal development of density and population structure (12 size classes from 0.3 to $20 \mathrm{~mm}$ ), 3 point sampling stations were sampled fortnightly from March 1997 to March 1998. Within the same period, spatial population dynamics was studied seasonally on a spatial grid $(700 \times 800 \mathrm{~m}, 43$ plots, distance between the plots $100 \mathrm{~m}$ ), which covered a range in bedlevel height from -50 to $+140 \mathrm{~cm}$ relative to mean tide level. Quantitative estimations of early recruitment, growth, and survival plus migration were calculated from the temporal and spatial population data. Early recruitment was highest at the higher tidal levels, where the sediment contained the smallest sand grains. In that same area, the highest disappearance of the juvenile $M$. balthica, caused by emigration and/or mortality, was observed. In the lower intertidal area, where the sediment contained larger sand grains, the number of recruits in the successive classes increased after Size Class 2 to $3 \mathrm{~mm}$. Based on further analysis of the population data, this increase in the number of recruits is concluded to have been mainly caused by immigration of $M$. balthica to the lower tidal levels. Since there seemed to be no important immigration into the entire spatial grid population, the migration may have been directed from the higher intertidal levels towards the lower. The strong initial early-recruitment pattern, supposed to be comprised of passive processes, became weaker for the successive size classes after Size Class 2 to $3 \mathrm{~mm}$, which resulted in a spatial distribution of Size Class 7 to $8 \mathrm{~mm}$ that was neither related to bedlevel height nor to sand grain size. Therefore, active migration processes are suggested to have been of higher importance than passive migration processes.
\end{abstract}

KEY WORDS: Passive resuspension - Active migration - Secondary settlement - Passive deposition · Habitat selectivity

Resale or republication not permitted without written consent of the publisher

\section{INTRODUCTION}

Spatial distribution patterns of bivalves in intertidal areas (100 to $1000 \mathrm{~m}$ scale) are the result of local differences in primary settlement of pelagic larvae, mortality and migration. The disappearance of marine bivalves used to be attributed to mortality, but nowa-

${ }^{*}$ Present address: National Institute for Coastal and Marine Management/RIKZ, PO Box 8039, 4330 EA Middelburg, Netherlands. E-mail: h.bouma@rikz.rws.minvenw.nl days we know from several field studies that migrations can be quantitatively very important. Many observations on drifting bivalves and other benthic animals (e.g. Beukema 1973, reviewed by Butman 1987), as well as mass migrations of almost entire populations, resulting in a secondary dispersion pattern, have been reported (e.g. Baggerman 1953, Bayne 1964, Beukema 1993, Armonies 1996).

After primary settlement of the pelagic larvae, individuals can re-enter the water column either by passive resuspension or by actively leaving the sediment. 
Passive resuspension is caused by hydrodynamic factors such as wave-action and/or high current velocity, and is related to weather conditions (e.g. Emerson \& Grant 1991, Armonies 1992, Commito et al. 1995). Some bivalves actively enter the water column by secreting a long mucous thread ('byssus thread') which increases the viscous drag and the floating capacity (Sigurdsson et al. 1976, Yankson 1986, Sörlin 1988). This active behaviour may be negatively related to the habitat quality of the specific location which, as we hypothesize, is related to food (supply and availability), benthos density (competition, interference, disturbance), predators and sediment composition (see also review by Armonies 1994a).

Once in the water column, the animals can be carried away by the tidal currents over distances of up to tens of kilometres by means of their byssus thread ('byssus-drifting') (e.g. de Vlas 1973, Sigurdsson et al. 1976, Lane et al. 1985, Beukema \& de Vlas 1989). After this passive tidal current transport, the survivors resettle in the sediment, either by passive deposition (e.g. Pratt 1953, Hannan 1984), or by active habitat selection (e.g. Meadows \& Campbell 1972, Woodin 1991). Both forms of secondary settlement are not mutually exclusive and may coexist within different spatial and temporal scales (see review by Butman 1987).

The present study deals with the population dynamics of the tellinid clam Macoma balthica (L.). After primary settlement of pelagic $M$. balthica larvae (ca 0.2 to $0.4 \mu \mathrm{m}$, e.g. Thorson 1946, Günther 1991, Armonies 1996), the postlarvae can leave the sediment (actively or passively) and re-settle elsewhere. For M. balthica, direct observations of byssus thread secretion (Sigurdsson et al. 1976, Beukema \& de Vlas 1989) and of entrance into the water column by means of swelling and protrusion of the foot (Sörlin 1988) have been reported. The field observations of diurnal and periodical rhythms in migratory activity of juvenile $M$. balthica (Armonies 1992) indicate that the clams are able to actively leave the sediment in their natural environment also.

As a facultative deposit feeder, Macoma balthica predominantly grazes with its inhalant siphon upon food on the surrounding sediment. Local primary production and deposition of food particles on the sediment renew the food supply. Due to their large siphonaction radius, individuals can interfere with each other and experience competition for food during their feeding activities. Levinton (1972) hypothesized that, on a local scale, competition is more likely in deposit-feeding communities than in suspension-feeding communities. This hypothesis was, for example, supported by the experiments of Kamermans et al. (1992, see also Peterson \& Skilleter 1994, Skilleter \& Peterson 1994,
Vincent et al. 1994). Assuming that under unfavourable conditions individuals are triggered to leave the sediment, density may play an important role in active migration.

Passive resuspension of Macoma balthica may make an important contribution to the number of migrating individuals, as demonstrated by the disturbance by strong wind conditions of the temporal rhythms in drifting M. balthica (Armonies 1992). Drifter abundance is significantly correlated with wind velocity and direction, which both exert their influence by causing modification of the tidal currents. Susceptibility to passive resuspension is expected to be highest for recently settled (small) individuals, because of their limited burying depth and capacity (e.g. Reading \& McGrorty 1978, Ratcliffe et al. 1981, Zwarts \& Wanink 1989). Recently settled spat may even be easier to resuspend than sand grains of the same size because of their lower specific gravity, but this also depends on their ability to attach to sediment particles (Roegner et al. 1995).

Beukema \& de Vlas (1989) experimentally tested the floating capacity of Macoma balthica with byssus threads and found their sinking rate to be directly proportional to shell length and inversely proportional to thread length. In the field, the same authors found specimens up to a size of $9 \mathrm{~mm}$ to be transported over distances up to tens of kilometres. High abundance of drifting M. balthica in the western Wadden Sea was observed in early spring and in winter (Beukema 1973), and the numbers of drifters in the northern Wadden Sea strongly decreased from June to October (Armonies 1992). In the Wadden Sea, mass migrations of $M$. balthica in their first summer are directed from the lower towards the higher tidal levels (Armonies \& Hellwig-Armonies 1992, Beukema 1993, Armonies 1996). Mass migrations in the subsequent winter, when the clams are ca 7 mo old, are directed from the higher towards the lower tidal levels (Beukema \& de Vlas 1989, Beukema 1993).

It is difficult to determine whether secondary dispersion patterns (on a 100 to $1000 \mathrm{~m}$ scale) are driven by passive deposition or by active habitat selection. Spatial distributions may correlate with sediment composition, but this does not necessarily indicate active habitat selection. The patterns also may be a consequence of the correlation between grain size distribution and current velocity (Armonies 1996). To gain more insight into the main factors establishing successive distribution patterns, it is helpful to make a distinction between the processes of primary settlement: leaving the sediment (actively vs passively) and re-entrance into the sediment (actively vs passively).

We chose a highly dynamic study site, with a gradient in bedlevel height and sand grain size distribution, 
to study the population dynamics of Macoma balthica on a range from low to highly dynamic locations. Considering the spatial scale of our study, and based on other findings at the same study site (Bouma et al. 2001), we assumed that at this tidal sandflat the early recruitment pattern of $M$. balthica is predominantly ruled by passive processes (see also Hannan 1984, Butman 1987, Woodin 1991, Armonies \& Hellwig-Armonies 1992). Furthermore, we assumed that the same hydrodynamic and sediment dynamic factors are involved in passive resuspension of the juveniles and in passive deposition of the drifting individuals. The highest early recruitment of $M$. balthica was observed at the highest, least dynamic, sampling locations (Bouma et al. 2001). We hypothesized that an intensification of this early recruitment pattern would be an indication for dominance of the passive processes (resuspension and deposition), whereas a flattening of the pattern would indicate dominance of the active processes (actively leaving and acticely selecting the habitat).

\section{MATERIALS AND METHODS}

Study site. The field research was carried out in the Westerschelde estuary (ca $300 \mathrm{~km}^{2}$ ), located in the south-western Netherlands (Fig. 1A). The Westerschelde estuary is highly dynamic, characterized by high tidal amplitude (ranging from $3.8 \mathrm{~m}$ in the western to $5.2 \mathrm{~m}$ in the eastern part), high current velocities, and turbid water. An intertidal sandflat, the 'Plaat van Baarland' (total surface $1.8 \mathrm{~km}^{2}$ ), in the mid-region of the estuary $\left(51^{\circ} 23^{\prime} \mathrm{N}\right.$ to $\left.3^{\circ} 52^{\prime} \mathrm{E}\right)$ was chosen as the study site (Fig. 1B,C). While the south-western part of the sandflat is highly dynamic (megaripples), the north-eastern part is weakly dynamic and not immersed during each high tide. A channel separates the sandflat from saltmarsh and land. The average tidal amplitude is $4.5 \mathrm{~m}$ and the maximum depth-averaged current velocity is approximately $1 \mathrm{~m} \mathrm{~s}^{-1}$. In the western half of the sandflat 3 point-sampling stations $(\mathrm{P}, \mathrm{Q}$ and $\mathrm{R})$ and a spatial grid $(700 \times 800 \mathrm{~m}, 43$ plots, distance between plots $100 \mathrm{~m}$ ) were set up by means of a differential Global Positioning System (dGPS) (Fig. 1C). Bedlevel heights of Stations $P, Q$ and $R$ were respectively $+40,+95$ and $+25 \mathrm{~cm}$ relative to mean tide level, while the spatial grid covered a range from -50 to $+140 \mathrm{~cm}$ relative to mean tide level. The silt content $(<63 \mu \mathrm{m})$ of Stations $\mathrm{P}, \mathrm{Q}$ and R was respectively 35,20 and $15 \%$, while the silt content at the spatial grid plots ranged from 10 to $40 \%$ (data from July 1997).

Biological sampling. Two different methods were used for the biological sampling. To capture early recruits of Macoma balthica (see Keogh \& Downes

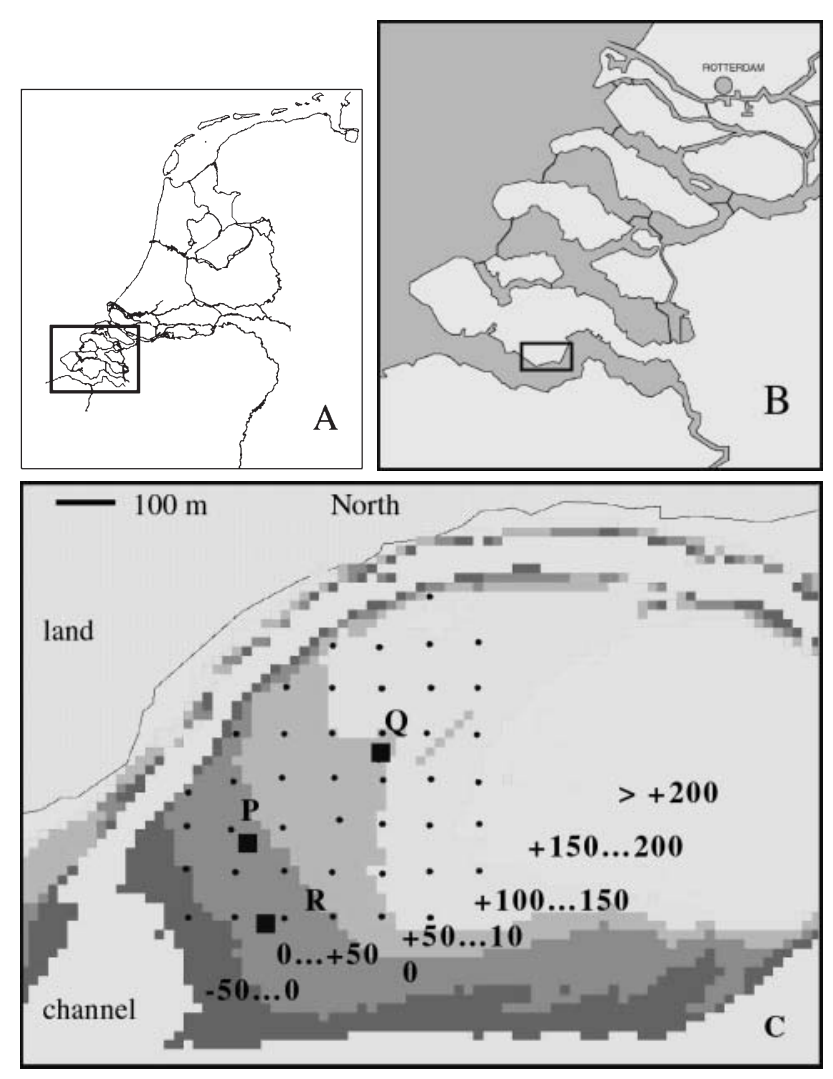

Fig. 1. (A) Location of the Westerschelde estuary in The Netherlands; (B) Location of the study site in the Westerschelde estuary $\left(51^{\circ} 23^{\prime} \mathrm{N}\right.$ to $\left.3^{\circ} 52^{\prime} \mathrm{E}\right)$; (C) Locations of the PointSampling Stations P, Q and R and the spatial grid (43 plots) at the study site. Bedlevel heights are indicated by various shadings with ranges in centimetres relative to mean tide level

1982, Olafsson et al. 1994), sediment samples were taken with a small plastic corer $(\varnothing 5.5 \mathrm{~cm})$ to a depth of $3 \mathrm{~cm}$. The samples were preserved with buffered (sodium tetraborate) formaldehyde ( $4 \%$ final concentration). In the laboratory, shortly after sampling, the samples were wet-sieved on meshes of $0.3 \mathrm{~mm}$ and $1 \mathrm{~mm}$, and the numbers of $M$. balthica in the 0.3 to $\mathrm{mm}$ mesh fraction were counted under a stereomicroscope ( $\times 40$ magnification). Sediment samples for $M$. balthica $>1 \mathrm{~mm}$ (i.e. macrobenthos) were taken with a stainless steel corer $(\varnothing 8 \mathrm{~cm})$ to a depth of $15 \mathrm{~cm}$. These samples were sieved in the field (mesh size $1 \mathrm{~mm}$ ), and the macrobenthos was preserved with buffered formaldehyde ( $4 \%$ final concentration). In the laboratory, $M$. balthica numbers were counted and shell lengths along the longest axis were measured with a caliper to the nearest $0.5 \mathrm{~mm}$.

Point-sampling. The point-sampling stations $\mathrm{P}, \mathrm{Q}$ and $\mathrm{R}(20 \times 20 \mathrm{~m}$, corners marked with thin wooden stakes $)$ were used to study the temporal population development of Macoma balthica. The density and size frequency distribution of $M$. balthica were monitored 
fortnightly from March 1997 to March 1998. The stations were divided into 4 quadrants of $10 \times 10 \mathrm{~m}$ and each quadrant was divided into 10 lines of $1 \times 10 \mathrm{~m}$. On each sampling occasion, 2 samples of early recruits and 2 samples of $M$. balthica $>1 \mathrm{~mm}$ were taken within 1 line per quadrant with $1 \mathrm{~m}$ distance between the samples. Thus, 8 replicate samples of both methods were taken per sampling station, yielding the total of 48 samples per sampling occasion: 8 (replicates) $\times 2$ (methods) $\times 3$ (stations). The sampling lines were moved 1 position (1 $\mathrm{m})$ between subsequent sampling occasions so that sampling in the same area only occurred after 10 sampling occasions (ca $5 \mathrm{mo}$ ). The $M$. balthica density per point-sampling station per sampling occasion per method was calculated as the mean of the numbers in the replicates and expressed as ind. $\mathrm{m}^{-2}$. Furthermore, the local populations were divided into 12 size classes ( 0.3 to $1 \mathrm{~mm}, 1$ to $2 \mathrm{~mm}, 2$ to $3 \mathrm{~mm}, \ldots, 9$ to $10 \mathrm{~mm}, 10$ to $15 \mathrm{~mm}$ and 15 to $20 \mathrm{~mm}$ ), and the densities per size class were calculated in the same way (ind. $\mathrm{m}^{-2}$ ).

Grid sampling. The spatial grid was used for repeated mapping of the Macoma balthica population. Shortly after the first high densities of early recruits ( 0.3 to $1 \mathrm{~mm}$ mesh fraction) were observed in the samples from the point-sampling stations, the 43 plots of the spatial grid were sampled for early recruits. Early recruit samplings at the spatial grid were carried out on 26 May, 2 June, 9 June and 25 June 1997. At each of the 43 plots, 3 replicate samples were taken in a northto-south line, with $1 \mathrm{~m}$ distance between the samples. The starting point of the line was chosen at random in an area of $5 \times 5 \mathrm{~m}$ surrounding the plots and was dif-

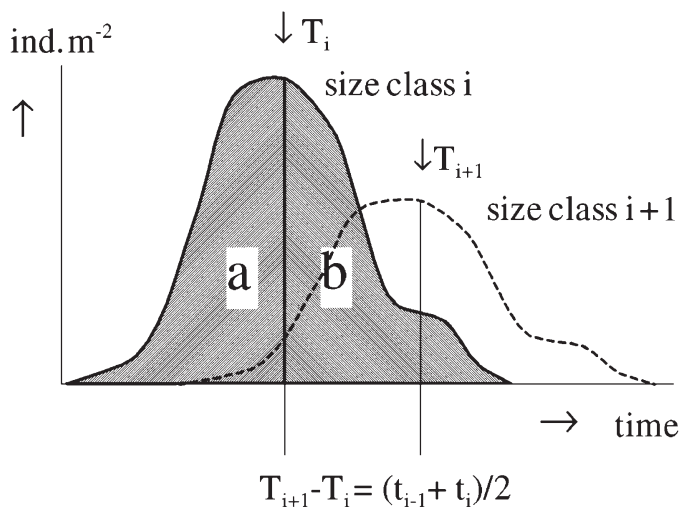

Fig. 2. Macoma balthica. Theoretical number of individuals through time for successive size-classes $(i, i+1, \ldots)$ in a population with no exchange of individuals. Arrows indicate centres of gravity of the curves $\left(T_{i}\right.$ and $\left.T_{i+1}\right)$, which move in time with $\left(t_{i-1}+t_{i}\right) / 2$, where $t_{i}$ is the time every individual spent, on average, in Size Class $i$. In our data set, the areas under the curves of the size classes $(a+b)$ were proportional to the number of recruits in the size classes (see last subsection of 'Materials and methods') ferent on each sampling date. The spatial grid was sampled for $M$. balthica $>1 \mathrm{~mm}$ on 6 occasions throughout the period March 1997 to March 1998: on 22 April, 28 June, 9 July, 8 October, 6 November 1997 and 18 March 1998. The number of replicates per plot was inversely proportional to density, estimated from the $\mathrm{P}, \mathrm{Q}$ and $\mathrm{R}$ station samples, and was respectively 5, $3,3,4,4$ and 4 . The replicate samples were taken in the same way as described for sampling of the early recruits. Density per plot per sampling date was calculated as the mean of the numbers in the replicates and expressed as ind. $\mathrm{m}^{-2}$. The plot populations were also divided into the same 12 size classes as the $\mathrm{P}, \mathrm{Q}$ and $\mathrm{R}$ station populations, and densities per size class were calculated (ind. $\mathrm{m}^{-2}$ ).

Measuring bedlevel height. The plots of the spatial grid were marked with 2 thin wooden stakes placed at exactly $1 \mathrm{~m}$ distance for measurement of bedlevel height (Fig. 2). In March $1997\left(T_{0}\right)$ a pvc-tube ( $\varnothing 43 \mathrm{~mm}$ ) was vertically driven to a depth of ca $15 \mathrm{~cm}$ into the sediment, exactly in the middle of the 2 stakes. The exact distance $\left(d_{0}\right)$ between the tube top and the sediment surface was measured by probing with a thin iron ruler. Also, the exact bedlevel heights $\left(h_{0}\right.$, in $\mathrm{cm}$ relative to mean tide level) of the tube locations were determined (dGPS postprocessing, accuracy $5 \mathrm{~cm}$ ). Therefore, the $T_{0}$-depths of the tubes in the sediment corresponded with the $T_{0}$-bedlevel heights of the plots. At the time of the bedlevel height measurement $\left(T_{X}=6\right.$ June), which was during the main biological sampling period, the actual depth $\left(d_{x}\right)$ of the tube was determined by means of probing with the ruler. The actual bedlevel height $\left(h_{x}\right)$ was derived by the equation $h_{x}=$ $h_{0}+\left(d_{X}-d_{0}\right)$.

Sediment composition. For analysis of the sediment composition, samples were taken at the spatial grid plots on 22 April, 2 June, 4 July and 6 November 1997. Four subsamples per plot were taken by means of a small plastic corer $(\varnothing 1 \mathrm{~cm})$ to a depth of $5 \mathrm{~cm}$. The subsamples were evenly distributed over the sediment ripples (ripple top, ripple trough, sheltered side and exposed side) and were pooled to form 1 sample for each grid plot. In the laboratory (Physical Geography, Utrecht) the samples were dried $\left(105^{\circ} \mathrm{C}\right)$, weighed $\left(w_{1}\right)$ and wet-sieved on a $63 \mu \mathrm{m}$ and $2000 \mu \mathrm{m}$ screen. The fractions 63 to $2000 \mu \mathrm{m}$ (sand) and $>2000 \mu \mathrm{m}$ were dried $\left(105^{\circ} \mathrm{C}\right)$ and weighed $\left(w_{2}\right.$ and $\left.w_{3}\right)$. The silt weight fraction $\left(<63 \mu \mathrm{m}, w_{4}\right)$ was derived $\left(w_{1}-w_{2}-w_{3}\right)$, and the silt content $(\%)$ calculated from $w_{4} / w_{2}$. The sand fraction (63 to $2000 \mu \mathrm{m}$ ) from 2 June was analyzed with a Coulter LS-230 laser-diffraction particle sizer. The mean sand grain size and the $\mathrm{D}_{50}$ and $\mathrm{D}_{90}$ (i.e. the sand grain size $(\mu \mathrm{m})$ at which respectively 50 and $90 \%$ of the sand grains are smaller than the mean) were determined from the sand grain size-frequency distribution 
Calculation of population statistics. We estimated the number of recruits in the successive size classes by a simplified model, based on that of Rigler \& Cooley (1974). We started with an analysis of the population development in time at the point sampling stations, since at these 3 stations the populations were sampled fortnightly, resulting in 27 sampling occasions $(x=$ 1...27). The densities $\left(n\right.$, in ind. $\left.\mathrm{m}^{-2}\right)$ in the successive size classes $(i, i+1, \ldots)$ are the result of recruitment into the size classes, mortality, migration, and growth out of the size classes. To estimate the number of individuals passing through a particular size class, one must know the area under the curve of numbers (i.e. densities, $n$ ) against time ( $t$, in days) for that size class (Fig. 3), and the length of time an individual spends in that size class. In the calculation, and in further data analysis, the size classes from 0.3 to $1 \mathrm{~mm}$ until 7 to $8 \mathrm{~mm}$ were used, since at the end of the study period most individuals had not reached a size larger than $8 \mathrm{~mm}$.

The area under the abundance curve for a particular size class $\left(A D_{i,}\right.$ ' 'animal days') is estimated by the trapezoidal rule, and equals the number of recruits in that size class times the number of days spent on average by each individual in that size class:

$A D_{i}=\sum_{x=1 \ldots 27}\left\{\left[\left(n_{X} \times t_{x}\right)+\left(n_{X+1} \times t_{X+1}\right)\right] \times\left[t_{X+1}-t_{x}\right]\right\} / 2$

Size class duration $\left(D_{i}\right)$ can be estimated by the interval between the centres of gravity of the abundance curves of 2 successive size classes. To calculate the centre of gravity of a certain size class $\left(T_{i}\right)$, the products of number $x$ days at the regular time intervals were summed and divided by the total number of individuals:

$$
T_{i}=\sum\left(n_{i} \times t_{i}\right) / \sum n_{i}
$$

The difference between the centers of gravity of 2 successive size classes $\left(T_{i+1}-T_{i}\right)$ equals half the time spent in both size classes, so the centers of gravity of the curves of successive size classes will be shifted in time by an amount $\left(t_{i}+t_{i+1}\right) / 2$. Strictly speaking, this is only true if all mortality occurs in the transition between the successive size classes and not within the stages themselves (e.g. Manly 1977), but the error is limited unless mortality rates are very high and very different between stages. The results of these duration estimations for all size classes yields a series of equations:

$$
\begin{gathered}
T_{2}-T_{1}=\left(t_{1}+t_{2}\right) / 2, \\
T_{3}-T_{2}=\left(t_{2}+t_{3}\right) / 2, \\
\ldots \ldots \ldots \ldots \ldots \ldots \\
\ldots \ldots \ldots \ldots \ldots \ldots \\
T_{8}-T_{7}=\left(t_{7}+t_{8}\right) / 2
\end{gathered}
$$

The number of unknowns is 1 more than the number of equations. Therefore, additional information has to be added from the pattern of development times in the successive size classes. In our data we observed a very
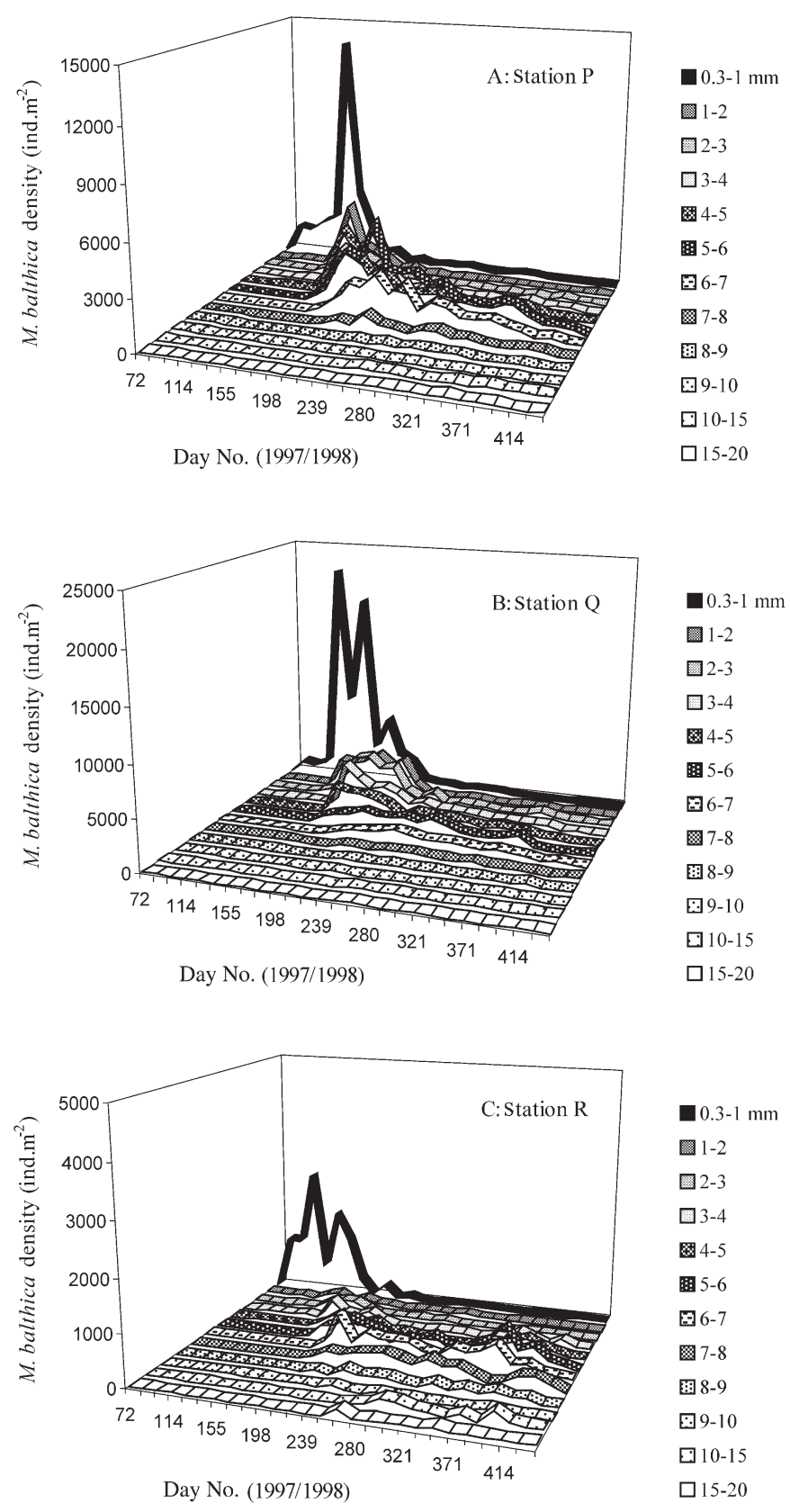

Fig. 3. Macoma balthica. Population development at the point-sampling stations. $x$-axes: time (day nos from March 1997 to March 1998); $y$-axes: successive size classes (mm); $z$-axes (note different scales): density

regular shift in time of the centres of gravity of the successive size classes (see below). Based on this, we assumed that the clams spent an equal length of time in the different size classes $\left(D_{i}\right)$.

Absolute numbers of recruits in the different size classes were much less relevant to our study than relative numbers, compared over space and between suc- 

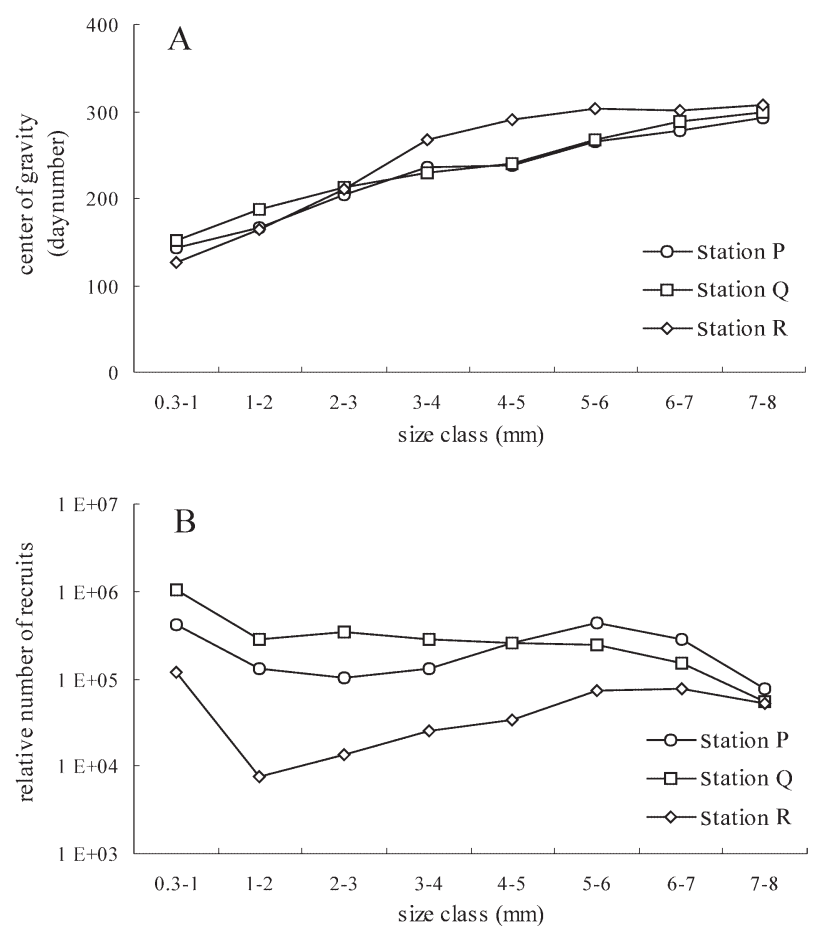

Fig. 4. Macoma balthica. Population development at the pointsampling stations. $x$-axes: successive size classes; $y$-axes: (A) centres of gravity of abundance curves (day no.), (B) relative number of recruits (exponential scale, e.g. $1 \mathrm{E}+04=10000$ ). Calculation of the centers of gravity and of the relative number of recruits is explained in the last subsection of 'Materials and methods'

cessive classes. We were able to use the number of animal days $\left(A D_{i}\right)$ in each size class as a relative indication of the number of recruits into that stage $\left(N_{i}\right)$, since in general $A D_{i}=N_{i} \times D_{i}$, and with equal $D_{i}$ values (as deduced from the linear increase in the centres of gravity) $A D_{i}$ becomes a relative measure of $N_{i}$ only.

\section{RESULTS}

\section{Point sampling}

Macoma balthica densities (ind. $\mathrm{m}^{-2}$ ) in the 12 size classes at the Point-Sampling Stations P, Q and R were calculated for all 27 sampling occasions (Fig. 4). At Sampling Station P (Fig. 4A), a steep density peak in Size Class 0.3 to $1 \mathrm{~mm}$ of 14000 ind. $\mathrm{m}^{-2}$ was observed on 21 May (Day 141). At Sampling Station Q (Fig. 4B) 2 peak densities in Size Class 0.3 to $1 \mathrm{~mm}$ occurred, the first of 22000 ind. $\mathrm{m}^{-2}$ on 7 May (Day 127), the second of 19000 ind. $\mathrm{m}^{-2}$ on 4 June (Day 156). Peak densities of Size Class 0.3 to $1 \mathrm{~mm}$ at Sampling Station $\mathrm{R}$ (Fig. 4C) were considerably lower than at the other 2 stations: 2500 and 1700 ind. $\mathrm{m}^{-2}$ on 24 April and 21 May respectively. At all 3 stations there was a strong decline in density between Size Class 0.3 to $1 \mathrm{~mm}$ and Size Class 1 to $2 \mathrm{~mm}$. From 4 June onwards, densities in the successive size classes subsequently increased and decreased because of growth through the successive size classes. Most $M$. balthica had reached a size between 5 and $8 \mathrm{~mm}$ on 26 August (Day 239) and virtually no further growth occurred during autumn and winter. Since at the end of the study period not all individuals had grown to a size larger than $8 \mathrm{~mm}, M$. balthica $>8 \mathrm{~mm}$ could not be used in the population data analysis. From the observation of annual growth rings on the clams in Size Classes 10 to $15 \mathrm{~mm}$ and 15 to $20 \mathrm{~mm}$ at Station $\mathrm{R}$, it was concluded that these individuals were not from the 1997 population. On 18 March 1998 (Day 447), the total density of all size classes at Stations P, Q and R was respectively 800, 875 and 275 ind. $\mathrm{m}^{-2}$, which was respectively 5.5, 4.0 and $11.0 \%$ of the densities of the highest early-recruitment peak.

The centres of gravity $\left(T_{\mathrm{i}}\right)$ of the abundance curves in Fig. 4 (see also earlier subsection 'Calculation of population statistics') were plotted against the successive size classes, yielding an almost straight line for all 3 sampling stations (Fig. 5A). Fig. 5 indicates that the clams spent an equal time in each size class. This conclusion justified the procedure of using relative numbers of recruits only, and is also an indication for linear growth. The relative number of recruits in the successive size classes (see earlier subsection 'Calculation of population statistics') was then plotted against the successive size classes (Fig. 5B). At all 3 stations, the highest number of recruits occurred in the first size class ( 0.3 to $1 \mathrm{~mm}$ ), and the number of recruits in the second size class (1 to $2 \mathrm{~mm}$ ) was considerably lower. The strongest decrease between these 2 size classes was found at Station $\mathrm{R}$, in the lowest intertidal region. The relative number of recruits in the Size Classes 1 to $2 \mathrm{~mm}$ until 5 to $6 \mathrm{~mm}$ slightly decreased at Station $\mathrm{Q}$, whereas at Station $\mathrm{P}$, and (even more obvious) at Station $\mathrm{R}$ the relative number of recruits in the successive size classes increased. In a closed population (i.e. with no exchange of individuals) theoretically the highest number of recruits enters the smallest size class, whereafter (due to mortality) the numbers of recruits in the successive size classes decrease with increasing size class. Thus, a closed population may have been present at Station Q (although from our data we cannot separate mortality from emigration), and, the increases in the relative number of recruits at the Stations $\mathrm{P}$ and $\mathrm{R}$ are not likely to have been caused by spatial differences in mortality. Therefore, we consider the increase in the relative number of recruits at the Stations $\mathrm{P}$ and $\mathrm{R}$ as an important indication for immigration. After Size Class 5 to $6 \mathrm{~mm}$ the number of recruits at all 3 stations again decreased. 
Fig. 5. Macoma balthica. Distribution (ind. $\mathrm{m}^{-2}$ ) on the spatial grid. (A) Size Class 0.3 to $1 \mathrm{~mm}$ (average density of the 4 sampling occasions in May and June 1997); (B) densities of clams (all size classes) on 18 March 1998
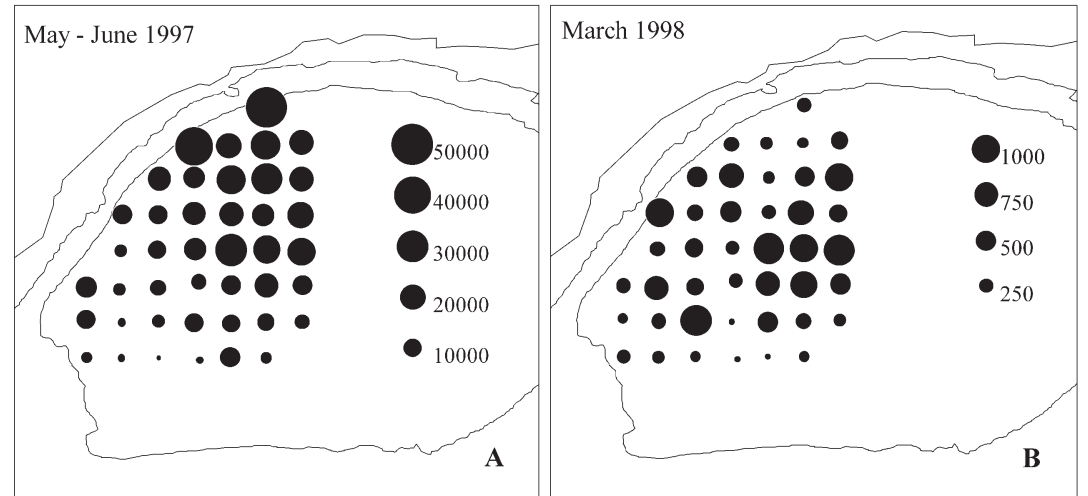

\section{Spatial grid}

A steep gradient in Macoma balthica densities in the smallest size class ( 0.3 to $1 \mathrm{~mm}$ ) was found on the spatial grid, with densities strongly increasing from southwest to north-east. The average densities on the 4 early-recruitment sampling occasions ranged from a minimum of 800 ind. $\mathrm{m}^{-2}$ in the south-west to a maximum of 49000 ind. $\mathrm{m}^{-2}$ in the north-east (Fig. 6A; details in Bouma et al. 2001). The strong spatial earlyrecruitment pattern flattened out in March 1998, when densities varied between 50 and 1250 ind. $\mathrm{m}^{-2}$ (Fig. 6B). Not only did the average early recruitment minimum equal $1.6 \%$ of the maximum and the final early recruitment minimum $4.0 \%$ of the maximum, but the spatial distribution of the densities was also much more homogeneous.

Since the 43 plots of the spatial grid were sampled 10 times throughout the period March 1997 to March
1998, it was possible to construct abundance curves of density per size class in time (comparable with Fig. 4). Since we concluded from the data of the point-sampling stations that the clams spent an equal amount of time in the successive size classes, we assumed that the area under the spatial grid abundance curves, like the area under the point-sampling station abundance curves, was proportional to the number of recruits in the successive size classes. A spatial overview of local population development at the separate grid plots is possible when the relative number of recruits per size class is plotted against the successive size classes (Fig. 7). The plots in the south-west consistently showed an increase in the relative number of recruits from Size Class 1 to $2 \mathrm{~mm}$ to Size Class 5 to $6 \mathrm{~mm}$. Since in a population with no exchange of individuals the number of recruits theoretically decreases in successive size classes due to mortality alone, the observed increase in the relative number of recruits is an

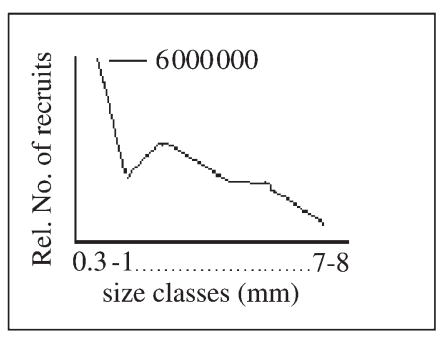

Fig. 6. Macoma balthica. Local population development in the spatial grid plots. $x$-axes: successive size classes $(0.3-1 \mathrm{~mm}$, $1-2 \mathrm{~mm} \ldots 7-8 \mathrm{~mm}) ; y$-axes; relative number of recruits; length of all $y$-axes is $6 \times 10^{6}$ (animal days)

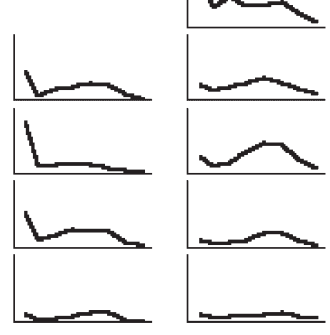

Macoma balthica
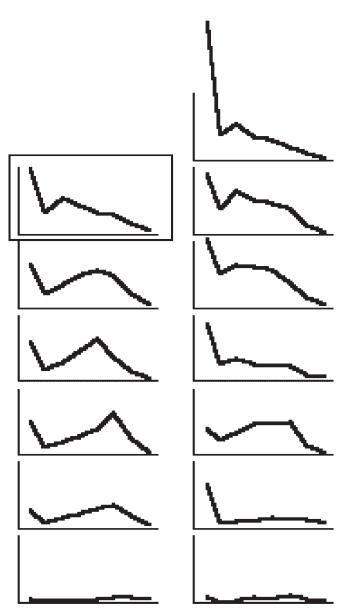
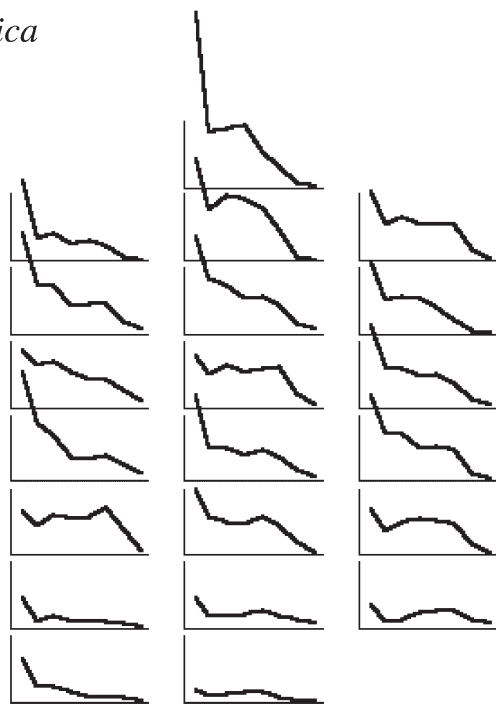

South 


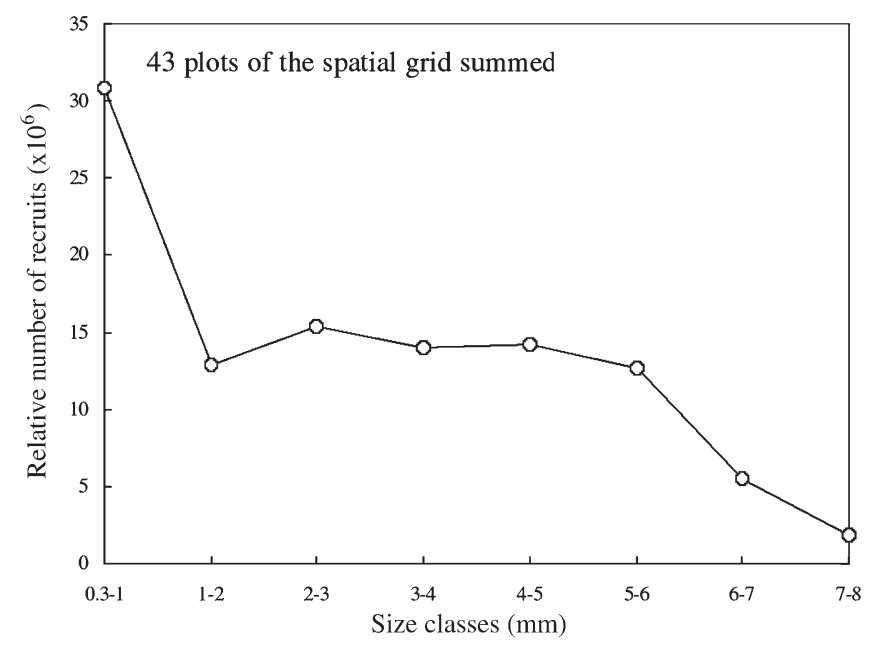

Fig. 7. Macoma balthica. The sum of the relative number of recruits (y-axis) per size class ( $x$-axis) in the 43 plots of the spatial grid

obvious indication for immigration (secondary settlement) of Macoma balthica in this area. However, without direct evidence that the clams are migrating (e.g. from mark and recapture or plankton-collection studies), local differences in mortality cannot completely be discarded (see 'Discussion').

We assumed that totalling the relative number of recruits of all 43 plots per size class provided a representative subsample of the Macoma balthica population on the spatial grid. The plot of the total relative number of recruits per size class versus the successive size classes in Fig. 8 shows no important increases. This is consistent with but not proof of a closed popula- tion. Comparison of direct and independent estimates of mortality rate with the rate of decrease of the relative number of recruits in the successive size classes would be necessary to reach final conclusions on the rate of immigration into the grid area. It was not possible to derive these estimates from our data base.

We investigated whether the spatial recruitment patterns in the successive size classes were related to bedlevel height and/or sediment composition. Table 1 shows Pearson product-moment correlation coefficients, whith significant probability levels indicated by asterisks. The spatial pattern of the relative number of recruits in the size classes from 0.3 to $1 \mathrm{~mm}$ to 5 to $6 \mathrm{~mm}$ was clearly positively related to bedlevel height (data from 6 June 1997). The relationship between Size Class 6 to $7 \mathrm{~mm}$ and bedlevel height was much weaker, and the relationship with bedlevel height was absent for Size Class 7 to $8 \mathrm{~mm}$. As demonstrated by Figs 9 \& 10, the relationship with bedlevel height becomes slightly stronger from Size Class 0.3 to $1 \mathrm{~mm}$ to Size Class 2 to $3 \mathrm{~mm}$, slightly weaker from Size Class 2 to $3 \mathrm{~mm}$ to Size Class 4 to $5 \mathrm{~mm}$, and shows a steep decrease from Size Class 4 to $5 \mathrm{~mm}$ to Size Class 7 to $8 \mathrm{~mm}$. The major change in the distribution pattern thus occurred in the size classes from 4 to $8 \mathrm{~mm}$.

The spatial recruitment patterns in all size classes up to 5-6 mm were significantly negatively correlated with the sand grain size variables $\mathrm{D}_{50}, \mathrm{D}_{90}$ and mean sand grain size (data from 2 June 1997), whereas no relationship with sand grain size existed for Size Classes 6 to $7 \mathrm{~mm}$ and 7 to $8 \mathrm{~mm}$ (Table 1). Pearson product-moment correlation coefficients for the suc-

Table 1. Macoma balthica. Pearson product-moment correlation coefficients of the relative number of recruits in the successive size classes as a function. ${ }^{*} \mathrm{p}<0.05,{ }^{* *} \mathrm{p}<0.01,{ }^{* * *} \mathrm{p}<0.001$

\begin{tabular}{|c|c|c|c|c|c|c|c|c|}
\hline & \multicolumn{8}{|c|}{ Size Class } \\
\hline & $0.3-1 \mathrm{~mm}$ & $1-2 \mathrm{~mm}$ & $2-3 \mathrm{~mm}$ & $3-4 \mathrm{~mm}$ & $4-5 \mathrm{~mm}$ & $5-6 \mathrm{~mm}$ & $6-7 \mathrm{~mm}$ & $7-8 \mathrm{~mm}$ \\
\hline $\begin{array}{l}\text { Bedlevel height } \\
6 \text { Jun, } \mathrm{n}=43\end{array}$ & $0.67^{* * *}$ & $0.75^{* * *}$ & $0.78^{* * *}$ & $0.73^{* * *}$ & $0.69^{* * *}$ & $0.55^{* * *}$ & $0.30^{*}$ & 0.11 \\
\hline $\begin{array}{l}\mathrm{D}_{50} \text { grain size } \\
2 \text { Jun, } \mathrm{n}=43\end{array}$ & $-0.45^{* *}$ & $-0.38^{*}$ & $-0.53^{* * *}$ & $-0.55^{* * *}$ & $-0.52^{* * *}$ & $-0.42^{* *}$ & -0.27 & 0.01 \\
\hline $\begin{array}{l}\mathrm{D}_{90} \text { grain size } \\
2 \text { Jun, } \mathrm{n}=43\end{array}$ & $-0.48^{* *}$ & $-0.40^{* *}$ & $-0.52^{* * *}$ & $-0.53^{* * *}$ & $-0.45^{* *}$ & $-0.31^{*}$ & -0.18 & -0.06 \\
\hline $\begin{array}{l}\text { Mean grain size } \\
2 \text { Jun, } n=43\end{array}$ & $-0.45^{* *}$ & $-0.38^{*}$ & $-0.53^{* * *}$ & $-0.56^{* * *}$ & $-0.53^{* * *}$ & $-0.43^{* *}$ & -0.29 & -0.01 \\
\hline $\begin{array}{l}\text { Silt content } \\
22 \mathrm{Apr}, \mathrm{n}=43\end{array}$ & -0.10 & -0.19 & -0.12 & -0.10 & -0.01 & -0.01 & 0.11 & -0.08 \\
\hline $\begin{array}{l}\text { Silt content } \\
2 \text { Jun, } n=43\end{array}$ & -0.11 & -0.13 & -0.06 & -0.01 & 0.11 & 0.20 & 0.23 & -0.00 \\
\hline $\begin{array}{l}\text { Silt content } \\
\quad 4 \mathrm{Jul}, \mathrm{n}=43\end{array}$ & -0.18 & -0.18 & -0.14 & -0.10 & 0.02 & 0.12 & 0.16 & 0.07 \\
\hline $\begin{array}{l}\text { Silt content } \\
\quad 6 \text { Nov, } n=41\end{array}$ & -0.13 & -0.14 & -0.07 & 0.10 & 0.20 & 0.15 & -0.05 & -0.19 \\
\hline
\end{tabular}



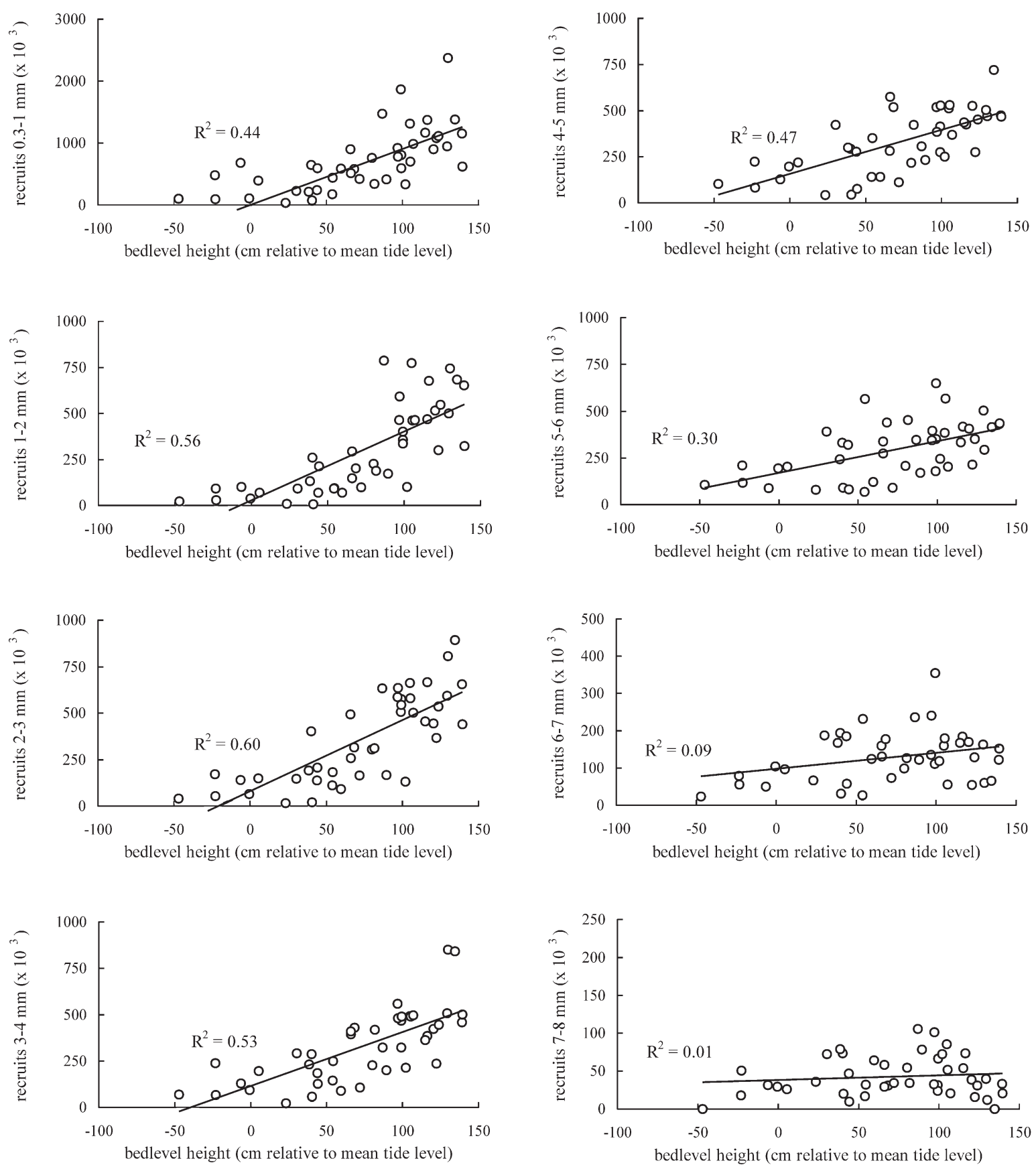

Fig. 8. Macoma balthica. Scatterplots of bedlevel height ( $\mathrm{cm}$ relative to mean tide level) ( $\mathrm{x}$-axes) and relative number of recruits per size class $(0.3-1 \mathrm{~mm}, 1-2 \mathrm{~mm}, 2-3 \mathrm{~mm} . .7-8 \mathrm{~mm})$ ( $y$-axes: note different scales) in the 43 plots of the spatial grid

cessive size classes revealed a pattern which is different from the correlation coefficients for bedlevel height (Fig. 10). The relationship with sand grain size variables decreased slightly from Size Class 0.3 to $1 \mathrm{~mm}$ to Size Class 1 to $2 \mathrm{~mm}$, slightly increased from Size Class 1 to $2 \mathrm{~mm}$ to Size Class 3 to $4 \mathrm{~mm}$, slightly decreased again from Size Class 3 to $4 \mathrm{~mm}$ to Size Class 4 to $5 \mathrm{~mm}$ and, as for the relationship with bedlevel height, steeply decreased from Size Class 4 to $5 \mathrm{~mm}$ to Size Class 7 to $8 \mathrm{~mm}$. None of the recruitment patterns in the successive size classes was significantly correlated with the silt content of the sediment (data from 22 April, 2 June, 4 July and 6 November 1997; Table 1). Bedlevel height and the sand grain size variables were significantly negatively related. The correlation coefficients of bedlevel height with $D_{50}$, the $D_{90}$ and the 


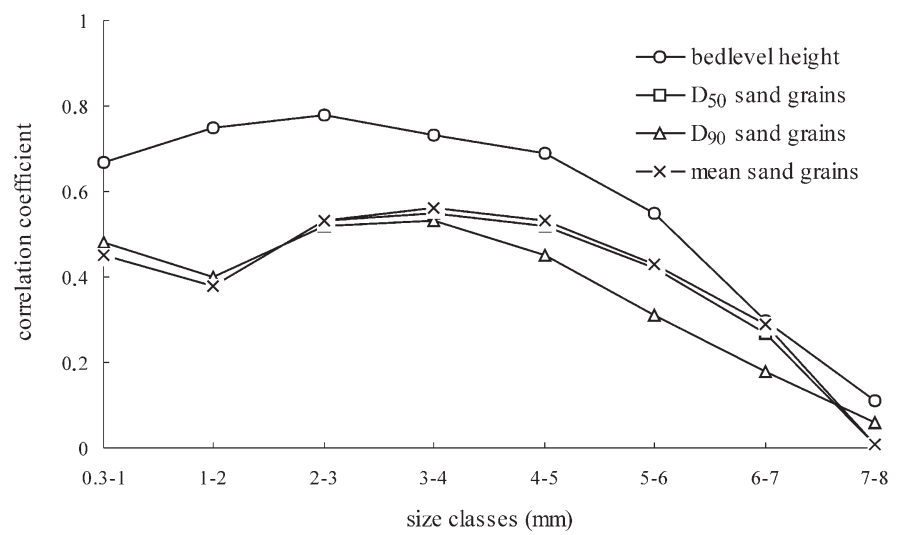

Fig. 9. Pearson product-moment correlation coefficients of bedlevel height, $\mathrm{D}_{50}, \mathrm{D}_{90}$ and mean of the sand grain size-distribution (y-axis), with the relative number of recruits in the successive size classes (x-axis) $\left(\mathrm{D}_{50}, \mathrm{D}_{90}=\right.$ sand grain size at which 50 and $90 \%$ of grains, respectively, are smaller than the mean)

mean of the sand grain size distribution were -0.30 , -0.43 and -0.33 respectively $(\mathrm{n}=43, \mathrm{p}<0.05)$. There was no significant correlation between bedlevel height and silt content.

In short, the main results from the spatial grid data are: (1) the spatial distribution of Macoma balthica from 0.3 to $6 \mathrm{~mm}$ in size was positively related to bedlevel height and negatively related to sand grain size-distribution; (2) the distribution pattern in relation to bedlevel height and sand grain size started to weaken after 3 to $4 \mathrm{~mm}$; (3) after $4 \mathrm{~mm}$, a major change in the distribution pattern occurred resulting in a distribution of $M$. balthica of 7 to $8 \mathrm{~mm}$ that was related neither to bedlevel height nor to sand grain size; and (4) silt content was not related to the spatial distribution of $M$. balthica in anysize class.

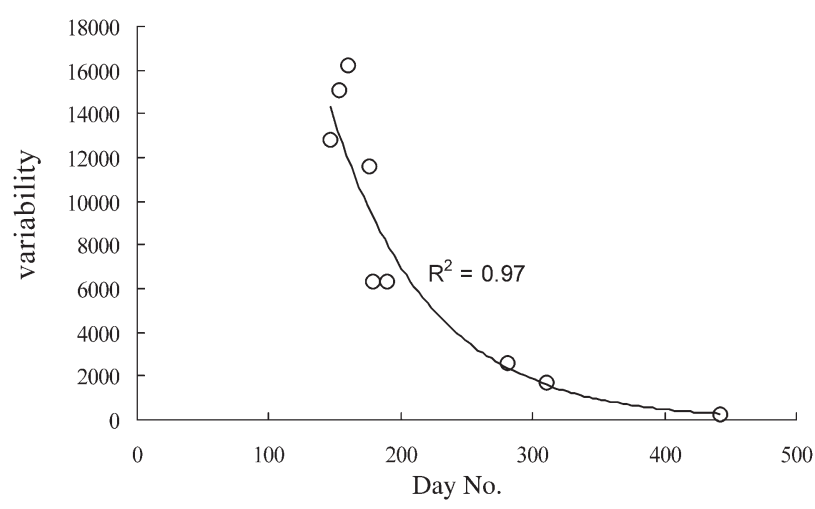

Fig. 10. Macoma balthica. Between-plot variability (ind. $\mathrm{m}^{-2}$ ) at the 9 grid sampling occasions after spatfall had begun. First sampling occasion was on 26 May 1997 (Day No. 146) and last on 18 March 1998 (Day No. 442). Variability was calculated as $1 / 43 \sum\left(n-n_{\text {avg }}\right)$, where $n=$ density per plot, $n_{\text {avg }}=$ average density of all 43 plots

\section{DISCUSSION}

The early-recruitment pattern of Macoma balthica ( 0.3 to $1 \mathrm{~mm}$ mesh fraction) was positively related to bedlevel height and negatively related to sand grain size. Quantitatively, we underestimated the early settlement densities, since we used this mesh fraction as the smallest size class whereas $M$. balthica is known to settle also at a size of $<0.3 \mathrm{~mm}$ (Günther 1991, Armonies \& Hellwig-Armonies 1992, Armonies 1996). Furthermore, the postlarvae in the 0.3 to 1 $\mathrm{mm}$ mesh fraction may already have redistributed after initial settlement (Armonies 1994a). We have described early recruitment of $M$. balthica and related factors (hydrodynamics and sediment dynamics) at the same study site in detail in another paper (Bouma et al. 2001).

The relationship of spatial distribution of the relative number of recruits to bedlevel height became slightly more marked between Size Class 0.3 to $1 \mathrm{~mm}$ and Size Class 2 to $3 \mathrm{~mm}$, whereas its relationship to sand grain size decreased slightly from Size Class 0.3 to $1 \mathrm{~mm}$ to Size Class 1 to $2 \mathrm{~mm}$ and increased slightly from Size Class 1 to $2 \mathrm{~mm}$ to Size Class 3 to $4 \mathrm{~mm}$. While most early recruits ( 0.3 to $1 \mathrm{~mm}$ ) settled in the highest, least dynamic area, even more slightly larger individuals were found in the same area, and less in the lower, more dynamic part of the grid. This intensification of the distribution pattern may have been caused by upwards transport of the early recruits, initiated by passive resuspension or by actively leaving the sediment (see below), or by spatial differences in predation pressure or other causes of mortality. The high overall decline in abundance of the smallest recruits supports the importance of mortality to these smallest size classes. Predation pressure on juvenile macrofauna is assumed to be higher in the lower intertidal than in the higher intertidal, because feeding time of macrofaunal predators (shrimps, crabs, infauna) and fishes is directly and positively related to inundation time (Reise 1985). Therefore, the intensification of the early recruit distribution pattern supports the importance of predation to the smallest size classes, since initial density was already lower at the lower tidal levels. Unfortunately, we did not directly study the mortality of juveniles (e.g. by counting empty shells), and no direct estimates of mortality rate are available.

The relationship between distribution pattern and bedlevel height and sand grain size started to weaken for Macoma balthica in the 3 to $4 \mathrm{~mm}$ size class. After $4 \mathrm{~mm}$, a major change in the distribution pattern occurred, resulting in a distribution pattern for 7 to $8 \mathrm{~mm}$ individuals that was related neither to bedlevel height nor to sand grain size. Analysis of the population data 
indicates that the flattening of the strong early-recruitment pattern was at least partly caused by immigration of 3 to $6 \mathrm{~mm}$ sized $M$. balthica into the lower intertidal part of the spatial grid, where the sediment contains the largest sand grains. Besides migration, local differences in mortality may have contributed to the changes in the distribution pattern. The main predators of 3 to $8 \mathrm{~mm}$ sized $M$. balthica are wading birds, since these clams are too large for ingestion by macrofaunal predators. However, in a population with no exchange of individuals, no increase in the number of recruits in the larger size classes could have occurred. Theoretically, in a closed population the number of recruits in the successive size classes would decrease, due to mortality alone. Therefore, we consider migration to have had a considerably more important role in the change in the distribution pattern than mortality. However, since direct observations of migrating individuals are lacking and no information on the importance of other factors such as predation are available, these conclusions remain speculative.

Hydrography is believed to be a major determinant for early spat distribution (e.g. Eckman 1983, Armonies 1992, Commito et al. 1995, Günther 1996). Therefore, early settlement should occur in an optimal area and the intensity of migrations be small. However, an area suitable for early recruits is not necessarily suitable for older individuals. After migration, Macoma balthica, are generally more evenly distributed than the initial early recruits. This was also the case at our study site, although autumn abundance (i.e. spatial density distribution on 6 November) was still higher at the higher intertidal levels. On the other hand, adult distribution may also be strongly patterned, and may even be the reverse of the initial early recruitment pattern (Armonies \& Hellwig-Armonies 1992, Armonies 1996). These authors described highest early recruitment in the lower intertidal levels, followed by higher autumn abundance in the higher intertidal. The difference between the population dynamics of $M$. balthica at our study site and theirs (northern Wadden Sea) is reflected in the between-plot variability in Fig. 10. While the between-plot variability in our study site decreased until March of the following year, Armonies \& Hellwig-Armonies (1992) observed an initial decrease, followed by an increase in between-site variability in October.

Taking the total relative number of recruits in all 43 plots as a representative subsample of the Macoma balthica population on the spatial grid, there seems to have been no important immigration from outside the grid area. However, direct and independent estimates of mortality rate would be needed to reach final conclusions on the rate of immigration into the grid area. If there was no immigration into the grid area, the immi- gration of mainly 3 to $6 \mathrm{~mm}$ sized $M$. balthica into the lower intertidal must have been the result of emigration from the higher intertidal. In such a case, the migration direction in relation to bedlevel height would be different from the summer migration of $M$. balthica in the western and northern Wadden Sea (Armonies \& Hellwig-Armonies 1992, Beukema 1993, Armonies 1996), which is directed towards the higher intertidal. In the Wadden Sea, the grown spat moves in the subsequent winter towards the middle and lower intertidal zones, where most adults live (Beukema 1993). Earlier studies in the western Wadden Sea (Beukema 1973, Beukema \& de Vlas 1989) reported migration of $M$. balthica from the higher towards the lower tidal levels, referring to a range from intertidal flats ('high') to the subtidal in the North Sea ('low'). Migration of mainly 3 to $6 \mathrm{~mm}$ sized $M$. balthica towards the spatial grid area, where the sediment contained relatively large sand grains, would be in agreement with the summer migration direction in the Wadden Sea.

We recognize that spatial differences in mortality may have contributed to the change in the distribution pattern of mainly 4 to $8 \mathrm{~mm}$ sized Macoma balthica, although from analysis of the population data we are convinced that migration played the major role. Therefore, we focus the rest of the discussion on migration aspects. As described in the 'Introduction', the early recruits can re-enter the water column either by passive resuspension or by actively leaving the sediment by means of a byssus thread. After passive transport with the tidal currents, they can re-settle elsewhere, either by passive deposition or by active habitat selection. The active and passive forms of re-entrance into the water column and of secondary settlement are not mutually exclusive and may coexist within different spatial and temporal scales. We hypothesized that intensification of the early recruitment pattern would indicate dominance of the passive migration processes, whereas flattening of the pattern would indicate dominance of the active migration processes.

Since the major change in the distribution pattern of Macoma balthica caused a flattening of the early recruitment pattern, migration of ca 3 to $6 \mathrm{~mm}$ sized clams was most likely dominated by active instead of passive migration processes. Migration of bivalves by means of byssus thread production has been examined in several previous laboratory and field studies (e.g. Baggerman 1953, Bayne 1964, Sigurdsson et al. 1976, Lane et al. 1985, Yankson 1986). For M. balthica, thread lengths of up to 100 times the shell length for $2 \mathrm{~mm}$ sized individuals and up to 30 times the shell length for $9 \mathrm{~mm}$ sized individuals were reported by Beukema \& de Vlas (1989). The production of byssus threads may be related to environmental conditions, as 
for example conspecific density and/or water current velocity (Sörlin 1988, Armonies 1994b). If the ca 3 to $6 \mathrm{~mm}$ sized $M$. balthica indeed migrated from the higher towards the lower part of the spatial grid, this would be a migration from a high-density towards a low-density area, similar to that of $M$. balthica in the Wadden Sea field studies mentioned above. Densitydependent growth of $M$. balthica has been detected in the field (Vincent et al. 1989, 1994), and intraspecific competition of $M$. balthica has been demonstrated in experimental studies (e.g. Kamermans et al. 1992). At the end of July in the present study, density in the higher plots was ca 14000 ind. $\mathrm{m}^{-2}$, and therefore competition for food and interference during deposit-feeding activities is likely to have occurred (e.g. Peterson \& Skilleter 1994, Skilleter \& Peterson 1994, Vincent et al. 1994). High conspecific abundance may have induced the migration, and active leaving of the sediment may have been density-dependent-regulated, especially when food was in a short supply. Unfortunately, no additional data on microphytobenthos densities or about the nutritional value of the fine deposits are available for our study site.

If active migration aspects were dominant, and the drifting ca 3 to $6 \mathrm{~mm}$ sized clams actively selected their habitat for secondary settlement, possibilities for growth, reproduction and survival should be better at the lower tidal levels. The actual selectivity during secondary settlement may not have been for sediment composition or food supply, but for locations with low conspecific density, where growth possibilities might be better because of less competition for food and less interference during deposit-feeding activities. Byssusthread floating or floating by means of protrusion of the foot (Sörlin 1988) may be a way to find a suitable habitat, although drifting individuals would still depend on hydrodynamic conditions. That the lower tidal zone may be advantageous for growth, can be argued on the ground of the filter-feeding possibilities it affords, since Macoma balthica is a facultative deposit-feeder. In the lower intertidal the clams are assumed to bury deeper and to filter-feed more frequently than in the higher intertidal (Levinton 1991). For filter-feeders, the lower intertidal probably is more profitable for growth, because of longer inundation time (e.g. Vincent et al. 1989, 1994), higher current velocities (e.g. Olafsson 1986, Nowell et al. 1989) and higher density of suspended food particles (Lin \& Hines 1994). Better growth of adult M. balthica in the lower intertidal was observed in the western Wadden Sea (Beukema 1993) and in other intertidal areas (e.g. Vincent et al. 1989, 1994, Harvey et al. 1993). On the other hand, the higher intertidal could be more advantageous for the deposit-feeding $M$. balthica because of its better light conditions for the growth of microphytobenthos, and its lower current velocities, causing enhanced deposition of food particles on the sediment (Peterson \& Skilleter 1994). Several field studies support the concept of better growth of $M$. balthica in the higher intertidal (e.g. Green 1973, Bachelet 1980, Armonies \& Hellwig-Armonies 1992). At our study site we observed no spatial differences in length of $M$. balthica at the end of the growing season.

Because the strong early-recruitment pattern, formed by passive processes (Bouma et al. 2001), was flattened out in autumn, we consider passive processes to have played a minor role in the changes in distribution pattern. Passive resuspension as the dominant process of re-entrance into the water column would have resulted in the strongest decrease in densities in the most dynamic, lower intertidal area, which was not the case. Since hydrography is supposed to determine whether early recruits settle onshore or offshore, it may also influence the direction of succeeding migrations. However, it is uncertain which pattern would arise from passive deposition of the water column drifters. Deposition is the result of sinking, turbulent mixing and the success of settlement once the sediment is hit. The sinking velocity of secondary settlers is dependent on body size and length of the byssus thread (Beukema \& de Vlas 1989).

The cause of migration may vary between study areas, as well as temporarily within the same area. Each individual requires a suitable range of environmental conditions and there will be no single cause of migration. In agreement with Armonies (1994a), the results of our study suggest that active behaviour of migrating macrofauna may overcompensate the constraints of hydrography. Whereas we expected that at this highly dynamic study site passive migration would be higher than active migration, even on this highly dynamic intertidal sandflat active migration seems to be of great importance to the population dynamics of Macoma balthica.

Acknowledgements. This study was financed by the National Institute for Coastal and Marine Management/RIKZ as part of the INGE*SEBES and DYNASTAR*ECOMOR projects, which aimed to investigate the relationship between estuarine morphology and benthic ecology. The manuscript was improved by the critical comments of 4 anonymous referees. We gratefully acknowledge inspiring and valuable discussions with Aad Smaal, Jaap Graveland, Harm Verbeek, Bart Kornman, Fred Twisk, Dick de Jong, Karel Essink, Herman Mulder, Peter Tydeman and Jetty Eppinga + (RIKZ). We also thank Emiel Brummelhuis and Rinus Markusse (NIOO) for counting the 0.3 to $1 \mathrm{~mm}$ sized spat in the 516 samples from the spatial grid. Most spatial presentations were made by means of Dotmap (Berrevoets), with the help of Cor Berrevoets and Bart Willemse (RIKZ). The field work could never have been realized without the help of all voluntary field workers. 


\section{LITERATURE CITED}

Armonies W (1992) Migratory rhythms of drifting juvenile molluscs in tidal waters of the Wadden Sea. Mar Ecol Prog Ser 83:197-206

Armonies W (1994a) Turnover of postlarval bivalves in sediments of tidal flats in Königshafen (German Wadden Sea). Helgol Meeresunters 48:291-297

Armonies W (1994b) Drifting meio- and macrobenthic invertebrates on tidal flats in Königshafen: a review. Helgoländer Meeresunters 48:299-320

Armonies W (1996) Changes in distribution patterns of 0group bivalves in the Wadden Sea: byssus-drifting releases juveniles from the constraints of hydrography. J Sea Res 35:323-334

Armonies W, Hellwig-Armonies M (1992) Passive settlement of Macoma balthica spat on tidal flats of the Wadden Sea and subsequent migration of juveniles. Neth J Sea Res 29: 371-378

Bachelet G (1980) Growth and recruitment of the tellinid bivalve Macoma balthica at the south of its geographical distribution, the Gironde estuary (SW France). Mar Biol 59:105-117

Baggerman B (1953) Spatfall and transport of Cardium edule L. Arch Néerl Zool 10:315-342

Bayne BL (1964) Primary and secondary settlement in Mytilus edulis L. (Mollusca). J Anim Ecol 33:513-523

Beukema JJ (1973) Migration and secondary spatfall of Macoma balthica (L.) in the western part of the Wadden Sea. Neth J Zool 23:356-357

Beukema JJ (1993) Successive changes in distribution patterns as an adaptive strategy in the bivalve Macoma balthica (L.) in the Wadden Sea. Helgoländer Meeresunters 47: 287-304

Beukema JJ, de Vlas J (1989) Tidal-current transport of thread-drifting postlarval juveniles of the bivalve Macoma balthica from the Wadden Sea to the North Sea. Mar Ecol Prog Ser 52:193-200

Bouma H, Duiher JMC, de Uries PP, Herman PMJ, Wolff WJ (2001) Spatial pattern of early recruitment of Macoma bathica (L) and Cerastoderma edule (L) on a highly dynamic intertidal sandflat. J Sea Res 45:79-93

Butman CA (1987) Larval settlement of soft-sediment invertebrates: the spatial scales of pattern explained by active habitat selection and the emerging role of hydrodynamical processes. Oceanogr Mar Biol Annu Rev 25:113-165

Commito JA, Thrush SF, Pridmore RD, Hewitt JE, Cummings VJ (1995) Dispersal dynamics in a wind-driven benthic system. Limnol Oceanogr 40:1513-1518

de Vlas J (1973) Migratie via getijstromen van jonge nonnetjes, Macoma balthica L., op en rond het Balgzand. Netherlands Institute of Sea Research, Texel

Eckman JE (1983) Hydrodynamic processes affecting benthic recruitment. Limnol Oceanogr 28:241-257

Emerson CW, Grant J (1991) The control of soft-shell clam (Mya arenaria) recruitment on intertidal sandflats by bedload sediment transport. Limnol Oceanogr 36:1288-1300

Green RH (1973) Growth and mortality in an arctic intertidal population of Macoma balthica (Pelecypoda, Tellinidae). J Fish Res Board Can 30:1345-1348

Günther CP (1991) Settlement of Macoma balthica on an intertidal sandflat in the Wadden Sea. Mar Ecol Prog Ser 76:73-79

Günther CP (1996) Small-scale patterns of recently settled Macoma balthica in the Wadden Sea. Senckenb Marit 26: $117-125$

Hannan CA (1984) Planktonic larvae may act like passive par- ticles in turbulent near-bottom flows. Limnol Oceanogr 29: $1108-1116$

Harvey M, Vincent B, Gratton Y (1993) Spatial variability of the length-specific annual production in shell, somatic tissue and sexual products of Macoma balthica (L.) in the Lower St. Lawrence Estuary. II. Large scale variability. Mar Biol 115:421-433

Kamermans P, van der Veer HW, Karczmarski L, Doeglas GW (1992) Competition in deposit- and suspension-feeding bivalves: experiments in controlled outdoor environments. J Exp Mar Biol Ecol 162:113-135

Keogh MJ, Downes BJ (1982) Recruitment of marine invertebrates: the role of active larval choices and early mortality. Oecologia (Berl) 54:348-352

Lane DJW, Beaumont AR, Hunter JR (1985) Byssus drifting and the drifting threads of the young postlarval mussel Mytilus edulis. Mar Biol 84:301-308

Levinton JS (1972) Stability and trophic structure in depositfeeding and suspension-feeding communities. Am Nat 106:472-486

Levinton JS (1991) Variable feeding behavior in three species of Macoma (Bivalvia: Tellinacea) as a response to water flow and sediment transport. Mar Biol 110:375-383

Lin J, Hines AH (1994) Effects of suspended food availability on the feeding mode and burial depth of the Baltic clam, Macoma balthica. Oikos 69:28-36

Manly BFJ (1977) A further note on Kiritani and Nakasuji's model for stage-frequency data including comments on the use of Tukey's jackknife technique for estimation of variances. Res Popul Ecol 18:177-186

Meadows PS, Campbell JI (1972) Habitat selection by aquatic invertebrates. Adv Mar Biol 10:271-382

Nowell RM, Jumars PA, Self RFL, Southard JB (1989) The effects of sediment transport and deposition on infauna: results obtained in a specially designed flume. In: Lopez G, Taghon G, Levinton J (eds) Ecology of marine deposit feeders. Springer-Verlag, New York, p 247-268

Olafsson EB (1986) Density dependence in suspension-feeding and deposit-feeding populations of the bivalve $\mathrm{Ma}$ coma balthica: a field experiment. J Anim Ecol 55:517-526

Olafsson EB, Peterson CH, Ambrose WG Jr (1994) Does recruitment limitation structure populations and communities of macro-invertebrates in marine soft sediments: the relative significance of pre- and post settlement processes. Oceanogr Mar Biol Annu Rev 32:65-109

Peterson CH, Skilleter GA (1994) Control of foraging behavior of individuals within an ecosystem context: the clam Macoma balthica, flow environment, and siphon cropping fishes. Oecologica 100:256-267

Pratt DM (1953) Abundance and growth of Venus mercenaria and Callocardia morrhuana in relation to the character of bottom sediments. J Mar Res 12:60-74

Ratcliffe PJ, Jones NV, Walters NJ (1981) The survival of Macoma balthica (L.) in mobile sediments. In: Jones NV, Wolff WJ (eds) Feeding and survival strategies of estuarine organisms. Plenum Press, New York, p 91-108

Reading CJ, McGrorty S (1978) Seasonal variations in the burying depth of Macoma balthica (L.) and its accessibility to wading birds. Estuar Coast Mar Sci 6:135-144

Reise K (1985) Tidal flat ecology. Springer Verlag, Berlin

Rigler FH, Cooley JM (1974) The use of field data to derive population statistics of multivoltine copepods. Limnol Oceanogr 19:636-655

Roegner C, André C, Lindegarth $M$, Eckman JE, Grant J (1995) Transport of recently settled soft-shell clams (Mya arenaria L.) in laboratory flume flow. J Exp Mar Biol Ecol 187:13-26 
Sigurdsson JB, Titman CW, Davies PA (1976) The dispersal of young post-larval bivalve molluscs by byssus threads. Nature 262:386-387

Skilleter GA, Peterson CH (1994) Control of foraging behavior of individuals within an ecosystem context: the clam Macoma balthica and interactions between competition and siphon cropping. Oecologia 100:268-278

Sörlin T (1988) Floating behavior of the tellinid bivalve Macoma balthica (L.). Oecologia 77:273-277

Thorson G (1946) Reproduction and larval development of Danish marine bottom invertebrates, with special reference to the planktonic larvae in the Sound (Øresund). Medd Komm Dan Fisk-Havunders Ser Plankton 4:1-523

Vincent B, Joly D, Brassard C (1989) Effets de la densité sur

Editorial responsibility: Otto Kinne (Editor)

Oldendorf/Luhe, Germany la croissance du bivalve Macoma balthica (L.) en zone intertidale. J Exp Mar Biol Ecol 126:145-162

Vincent B, Joly D, Harvey M (1994) Spatial variation of the bivalve Macoma balthica (L.) on a tidal flat: effects of environmental factors and intraspecific competition. J Exp Mar Biol Ecol 181:223-238

Woodin SA (1991) Recruitment of infauna: positive or negative cues? Am Zool 31:797-807

Yankson K (1986) Observations on byssus systems in the spat of Cerastoderma glaucum and C. edule. J Mar Biol Assoc UK 66:277-292

Zwarts L, Wanink J (1989) Siphon size and burying depth in deposit- and suspension-feeding benthic bivalves. Mar Biol 100:227-240

Submitted: May 5, 2000; Accepted: February 6, 2001

Proofs received from author(s): November 22, 2001 